V. V. Kmyta, V. Y. Garbuzova, E. N. Prystupa, L. N. Prystupa Bcl1

polymorphism of glucocorticoid receptor gene in patients with

bronchial asthma with obesity // Cytol Genet. - 2016. - 50(3). - pp

178-182 DOI: 10.3103/S0095452716030063

UDK: 616.248-06:612.017:575.113.2

\title{
Bcl1 POLYMORPHISM OF GLUCOCORTICOID RECEPTOR GENE IN PATIENTS WITH BRONCHIAL ASTHMA WITH OBESITY
}

\author{
V.V. KMYTA ${ }^{1}$, V.Y. GARBUZOVA ${ }^{1}$, E.N. PRYSTUPA ${ }^{2}$, L.N. PRYSTUPA ${ }^{1}$ \\ 1 Sumy State University \\ ${ }^{2}$ Lviv State University of Physical \\ Culture E-mail: Vlady_dytko@ukr.net
}

The objective of this investigation was to analyze possible

(c) V.V. KMYTA, V.Y. GARBUZOVA, E.N. PRYSTUPA, L.N. association between Bcll polymorphism of glucocorticoid receptor gene and obesity in patients with bronchial asthma (BA). The study involved 188 patients with bronchial asthma and 95 apparently healthy adult individuals. Generally accepted assessments and examinations for BA diagnosis, and anthropometric, molecular-genetic and statistic methods of investigation were used in the research. It was found out that the patients with $B A$ demonstrated higher body mass index (BMI) and higher ratio of fat centralization much more often, than the control group. Genotypes distribution for Bcll polymorphism in patients with $B A$ showed a statistically significant difference between patients with different BMI unlike the control group. Comparison of genotype frequency for Bcll polymorphism in glucocorticoid receptor gene in individuals with different ratio of fat centralization in the control group and in the patients with BA separately showed statistically significant differences in the distribution of gene allelic variations only among the patients with $B A$. It was demonstrated that $G / G$ genotype in the patients with visceral obesity was associated with $B A$.

Key words: bronchial asthma, obesity, Âcl1 polymorphism, glucocorticoid receptor gene.

Introduction. A plenty of evidence concerning the role of obesity in bronchial asthma occurrence (BA) $[1,2]$ and deterioration of BA control [3] has been reported in recent years. Thus, more than 40 crosso-ver studies and case-control investigations showing the connection between BA and obesity have been carried out since 1990 .

The mechanisms of this association have not been studied well yet, but their comprehension includes the following complex of factors: food with a low antioxidant value; low physical activity; gastroesophageal reflux disease; mechanical restrictions of respiratory movements volume caused by thoracicoabdominal fat depot; systemic inflammations induced by mediators of adipose tissue; genetic fac-tors $[1,4,5]$. 
Obesity contributes not only to occurrence of BA, but also to more severe BA course due to caus-ing a certain phenotype of disease and decreasing the effectiveness of treatment. Still, the associated pathogenic mechanisms in BA and obesity require further studies. This problem borders on three directions of scientific research: investigation of the metabolic disorders in obesity; further conceptual development of BA as a chronical disease, accompanied by a persistent inflammation; search for their common genetic determinants.

BA and obesity are multifactorial diseases, which are influenced by both genetic factors and environmental factors [6]. It is assumed that the common genetic factors of these two diseases can partly explain the data of epidemiological investigations, which confirm a close association between BA and obesity. More than 100 genes were found associated with BA occurrence and, in particular, with allergen-specific $\lg E$ production (atopy), development of bronchial hyperreactivity, synthesis of mediators of inflammation (cytokines, chemokins, growth factors), correlation between the types of Th1- and Th2-lymphocyte immune response [1, 2, 4].

Certain investigations showed that genetic factors of BA and obesity overlap each other [7-9]; this indicates that they have common genetic predisposition. Thus, BA and obesity are associated with the genes, which encode ü-adrenergic receptor (locus 5q, ADRB2 gene), insulin-like growth factor (locus 12q, IGF1 gene), IL-1I (locus 12q, IL1I gene), leukotriene A4 hydroxylase (locus 12q, LTA4H gene), GR (locus 5q, NR3C1 gene), signal transducers and activators of transcription (locus 12q), TNF (locus 6p, TNF gene), uncou-pling protein (locus 11q13, gene UCP2 and 3), etc. [6].

Among candidate genes of obesity and BA there is a single copy of glucocorticoid receptor (GR) gene in humans and it is located on chro- 
mosome 5 (locus 5q31.3). A few polymorphisms of this gene are described; they are related to anthropometric parameters $[10,11]$. The most common and well-studied polymorphism is Bcll (C647G, rs41423247). Depending on population, G-allele frequency of the polymorphism constitutes more than $30 \%$. Some investigations have proved the association of Bcll polymorphism with body mass index (BMI) and abdominal obesity [10, 11]; a few studies have shown its association with BA [12]. Still, no investigations related to the connection of Bcll polymorphism with body mass index in BA patients were carried out.

The objective of this investigation was to analyze possible association between Bcll polymorphism of GR gene and obesity in patients with BA.

Materials and methods. Prior to the study, all patients provided written informed consent to participate. 188 patients with BA have been examined. The control group consisted of 95 apparently healthy adult individuals. Among 188 patients with BA were 124 women $(66 \%)$ and 64 men (34\%), in the control group - 50 (52.6\%) and $45(47.4 \%)$ respectively. The average age of patients with BA accounted 46,2 $\pm 0,83$ years, and for the control group $-44,1 \pm 1,53$ years. There were no statistically significant differences in the ethnic component in the control group and in the patients with BA. We measured body mass, height, body mass index (BMI), and deter-mined the ratio of fat centralization (RFC). BMI and RFC parameters were estimated according to $\mathrm{WHO}$ recommendations.

The determination of allelic polymorphism in exon 2 of Bcl1 GR gene (C647G; rs41423247) was performed by means of polymerase chain reaction with subsequent analysis of restriction fragment length polymorphism (according to the instruc- tions of Fleury [15]) with modifications. Statistical analysis of the results was performed using SPSS17 program. The obtained results were subjected to descriptive statistical analysis with calculation of arithmetic means and standard deviations. The significance of differences between mean values was determined by means of Pearson $Z^{2}$, with $P<$ 0.05 adopted as the significance level. Logistic regres-sion, analysis of variance, Fisher criterion have been used as well.

Results. The compliance test for Bcl1 polymorphism genotypes distribution and the Hardy-Weinberg equilibrium showed that deviations from the equilibrium were not statistically significant either in the control group $\left(Z^{2}=0,01 ; p>0,05\right)$, or in the main one $\left(Z^{2}=3,53 ; p>0,05\right)$, so the allele correlations in both groups didn't significantly differ from the predicted $(\partial>0.05)$. The control group had the following genotypes frequency for Bcl1 polymorphism of GR gene: C/C, Ñ/G, G/G $0,421 / 0,453 / 0,126$, respectively. In patients with BA the frequency of studied genotypes made: $0,228 / 0,426 / 0,346$, respectively. Thus, the analysis of genotype frequencies for Bcl1 polymorphism of GR gene asserted that there is a statistically signifi-cant difference in the distribution of allelic variants of the gene between patients with $B A$ and healthy individuals $\left(Z^{2}=19,234 ; p=0,001\right)$.

Among patients with $\mathrm{BA}$, normal body mass (NBM) was found in $50,5 \%$ of individuals, overweight $-15,4 \%$, obesity $-34 \%$. In the control group, $76,8 \%$ of the investigated had NBM, $20 \%$ had overweight and $3,2 \%$ had obesity. It was demonstrated that obesity occurs more often among BA patients, than in the control group ( $ठ=$ $0,001)$.

The patients with BA had higher BMI parameter, than the individuals in the control group

Table 1. Body mass index in the groups depending on the variations of genotype for Âcl1 polymorphism of glucocorticoid receptor gene

\begin{tabular}{l|c|c|c|c|c}
\hline \multicolumn{1}{c|}{ Groups } & C/C & C/G & G/G & F & $P_{1}$ \\
\hline Control & $23.5 \pm 0.46(40)$ & $23.6 \pm 0.45(43)$ & $23.1 \pm 0.61(12)$ & 0.093 & 0.9126 \\
BA & $24.6 \pm 0.68(43)$ & $25.2 \pm 0.57(80)$ & $31.3 \pm 0.74(65)$ & 30.39 & 0.0001 \\
$\partial_{2}$ & 0.1905 & 0.0608 & 0.0001 & & \\
\hline
\end{tabular}

Note. F - Fisher criterion; $\partial_{1}$ - significance of the differences among genotypes according to the data of the one-way analysis of variance; $\partial_{2}$ - significance of the differences between the control group and BA patients according to the t-test; figures in the braces - the number of patients. 
$\left(27,2 \pm 0,44 \mathrm{~kg} / \mathrm{m}^{2}\right.$ vs. $23,5 \pm 0,29 \mathrm{~kg} / \mathrm{m}^{2} ;$ ठ $<<$ 0.001 ). Table 1 depicts indicators of $\mathrm{BMI}$ in control group and in patients with BA, which have different genotype by Bcll polymorphism of the GR gene. The obtained data showed that BMl values didn't significantly differ in carriers with different genotypes for Bcll polymorphism in the control group $(ð=0,91)$. However, dependence between Bcll polymorphism and BMI parameters was found in patients with $B A: G / G$ genotype carriers had higher BMI $\left(31,3 \pm 0,74 \mathrm{~kg} / \mathrm{m}^{2}\right)$, than representatives with others genotypes. Comparing the groups, we found out that BMI values didn't differ significantly in $C / C$ and $C / G$ genotypes carriers. However, $G / G$ homozygotes among BA patients had higher $\mathrm{BMI}$, than those in the control group: $31,3 \pm 0,74 \mathrm{~kg} / \mathrm{m}^{2}$ vs $23,1 \pm 0,61 \mathrm{~kg} / \mathrm{m}^{2}$ (ठ $==$ $0,0001)$.

Table 2 represents the results obtained during the study of GR allelic variations distribution for Bcll polymorphism in patients with $B A$ and apparently healthy individuals having different BMI values. Differences in the distribution of different geno-type variations for Bcll polymorphism of GR gene between patients with BA and apparently healthy individuals with normal body mass were not statisti-cally significant, because the $\partial$ value determined by Pearson's chi-squared test $\left(Z^{2}\right)$ was higher than 0,05 and equaled to 0,275 , at same time this differences among BA patients and healthy individuals with increased body weight were statistically significant $(ð=0,0001)$.

The analysis of genotypes distribution for this polymorphism in patients with BA showed significant differences among patients with different body mass. $\mathrm{P}$ was lower, than 0,0001 by Pearson's chi- squared test $\left(Z^{2}\right)$. It was established that $B A$ patients with obesity mostly had $\mathrm{G} / \mathrm{G}$ genotype.

The research on the visceral obesity frequency demonstrated that $78,9 \%$ of apparently healthy individuals had normal ratio of fat centralization, while the rest had a higher ratio. Among the patients with BA, $54,8 \%$ had a high ratio of fat centraliza-tion, $45,2 \%$ had normal value. It was established that the patients with BA demonstrated higher ratio of fat centralization much more often, than others $(\delta=0,0001)$.

As comparing the data of genotype frequency for Bcll GR gene polymorphism in the control group and BA patients group with normal fat centraliza-tion parameters, it was observed that the differences in distribution of GR gene allelic variations were not statistically significant $(ð=0,106)$. Where there was a higher ratio of fat centralization, a statistically significant difference in genotype distribution was reported $(ð=0,001)$ (Table 3$)$.

As comparing the data of genotype frequency for this polymorphism in exon 2 of GR gene in the control group and BA patients group with different fat centralization parameters, we found a statis-tically significant difference in the distribution of allelic variations only among the patients with $B A$. Thus, the analysis of genotypes distribution depend-ing on the ratio of fat centralization in patients with asthma showed a statistically significant difference $\left(Z^{2}=25,5\right.$; $\partial=0,001)$. C/G genotype was mostly found in patients without visceral obesity $(56,3 \%)$, while $G / G$ genotype was peculiar for the patients with high ratio of fat centralization (52,9\%). Con-sequently, GG homozygotes have higher ratio of fat centralization, than the major allele homozygotes or heterozygotes.

Table 2. Distribution of genotypes for Âcl1 polymorphism of glucocorticoid receptor gene depending on body mass index

\begin{tabular}{|c|c|c|c|c|c|c|c|c|}
\hline \multirow{3}{*}{ Genotype } & \multicolumn{4}{|c|}{$\mathrm{BMI}<25 \mathrm{~kg} / \mathrm{m}^{2}$} & \multicolumn{4}{|c|}{$\mathrm{BMI} \cdot 25 \mathrm{~kg} / \mathrm{m}^{2}$} \\
\hline & \multicolumn{2}{|c|}{ Control } & \multicolumn{2}{|c|}{ BA } & \multicolumn{2}{|c|}{ Control } & \multicolumn{2}{|c|}{$\mathrm{BA}$} \\
\hline & $n$ & $\%$ & $N$ & $\%$ & $n$ & $\%$ & $N$ & $\%$ \\
\hline $\mathrm{C} / \mathrm{C}$ & 29 & 39.7 & 27 & 28.4 & 11 & 50 & 16 & 17.2 \\
\hline $\mathrm{C} / \mathrm{G}$ & 34 & 46.6 & 55 & 57.9 & 9 & 40,9 & 25 & 26.9 \\
\hline \multirow[t]{2}{*}{$\mathrm{G} / \mathrm{G}$} & 10 & 13.7 & 13 & 13.7 & 2 & 9,1 & 52 & 55.9 \\
\hline & \multicolumn{4}{|c|}{$Z^{2}=2.58 ; \succsim=0.275$} & \multicolumn{4}{|c|}{$Z^{2}=17.641 ; \partial=0.001$} \\
\hline
\end{tabular}


We have studied BA risk depending on the genotype of Âcl1 GR gene polymorphism in patients. Taking $\tilde{N} / \tilde{N}$ genotype as a reference one, we demonstrated that $\mathrm{G} / \mathrm{G}$ homozygous type of GR ge-ne is likely to cause a fivefold increase of $B A$ risk (OR $=$ $5.038, \mathrm{Cl}-95 \%$ 2.377-10.682, ð<0.001).

Odds ratio calculated for the association between Bcl1 gene polymorphism and predisposition to visceral obesity in BA patients, thus G/G genotype carriers showed a higher risk of visceral obesity comparing to the patients with $\mathrm{C} / \mathrm{C}$ genotype $(\mathrm{OR}=3.13, \mathrm{Cl}-95 \% 1.4-6.97$; $0<0.01)$.

Discussion. The objective of our research was to study the role of the most common and well studied polymorphisms - Bcll polymorphism in intron 2 of GR gene - in occurrence of obesity in BA pa-tients. It was reported in the literature that the Bcll polymorphism of GR gene was associated with the accumulation of visceral fat, which is a risk factor for atherosclerosis, cardiovascular diseases, obesity and BA [10,12].

A number of studies demonstrated an association between $\mathrm{G} / \mathrm{G}$ genotype for the Bcll polymorphism and obesity. Thus, Rosmond et al. [7] figured out that $G$ allele was related to increase of $\mathrm{BMI}$, ratio of fat centralization, saggital diameter. Other inves-tigations also reported on the connection between $\mathrm{G}$ allele and visceral fat mass increase $[8,11]$. Three large studies showed the connection between Bcll polymorphism and visceral obesity among middle age individuals [7, 8, 11]; moreover, G allele was associated with higher mass of visceral fat indepen-dent of the total body fat mass [8].

Bcll polymorphism was associated with abdominal obesity, though a few studies found no significant differences in Bcll polymorphism ge- notype frequency in individuals with or without obesity [13]. Our investigation established that BMI values didn't differ much among the con-trol group individuals with different genotypes for Bcl1 GR gene polymorphism. However, the ana-lysis of genotypes distribution for this polymor-phism in patients with asthma showed significant differences among patients with different body mass ( $\circlearrowright<0,0001$ by $Z^{2}$ Pearson's chi-squared test. Thus, G/G genotype for Bcll polymorphism was related to higher BMI as compared with other genotypes and the control group $(\delta=0,0001)$. This indicated that body mass in patients with asthma depended on the genotype for Bcl1 GR gene polymorphism; besides, G/G genotype was related to the maximum $\mathrm{BMI}$ values.

The connection between BMI and the genotypes for Bcll polymorphism of GR gene in patients with BA, as well as the absence of such connection in the control group, is explained by the fact that $G / G$ genotype frequency in the patients was higher, than that in apparently healthy individuals. These observations are congruent with the data given by Polish scientists [12]. In its turn, this can testify that $G$ allele homozygotes are more predisposed to developing BA and obesity, than $\mathrm{C} / \mathrm{C}$ homozygotes and heterozygotes. Therefore, Bcll polymorphism is associated with occurrence of $\mathrm{BA}$ and obesity in patients with BA.

The analysis of possible association between the genotypes for Bcll GR gene polymorphism and visceral fat deposition stated no statistically significant differences in the distribution of GR gene allelic variations, if the ratio of fat centralization is normal $(\partial=0,106)$. In case of an increased ra-tio, differences in genotype distribution are present

Table 3. Distribution of genotypes for Âcl1 polymorphism of glucocorticoid receptor gene depending on the ratio of fat centralization

\begin{tabular}{|c|c|c|c|c|c|c|c|c|}
\hline \multirow{3}{*}{ Genotype } & \multicolumn{4}{|c|}{ Normal RFC } & \multicolumn{4}{|c|}{ Increased RFC } \\
\hline & \multicolumn{2}{|c|}{ Control, $n=75$} & \multicolumn{2}{|c|}{$\mathrm{BA}, n=103$} & \multicolumn{2}{|c|}{ Control, $n=20$} & \multicolumn{2}{|c|}{ BA, $n=85$} \\
\hline & $n$ & $\%$ & $N$ & $\%$ & $n$ & $\%$ & $N$ & $\%$ \\
\hline $\mathrm{C} / \mathrm{C}$ & 29 & 38.7 & 25 & 24.3 & 11 & 55 & 18 & 21.2 \\
\hline $\mathrm{C} / \mathrm{G}$ & 36 & 48.0 & 58 & 56.3 & 7 & 35 & 22 & 25.9 \\
\hline \multirow[t]{2}{*}{$\mathrm{G} / \mathrm{G}$} & 10 & 13.3 & 20 & 19.4 & 2 & 10 & 45 & 52.9 \\
\hline & \multicolumn{4}{|c|}{$Z^{2}=4.5 ; ð=0.106$} & \multicolumn{4}{|c|}{$Z^{2}=13.9 ; \succsim=0.001$} \\
\hline
\end{tabular}


( $\circlearrowright=0,001$ ). Thus, $C / G$ genotype was mostly found in the patients without visceral obesity, while G/G genotype was peculiar for the patients having visceral obesity. On the other hand, it was observed that in the group of BA patients: $58,1 \%$ of $\mathrm{C} / \mathrm{C}$ genotype carriers had normal ratio of fat centraliza-tion and $41,9 \%$ had a high ratio; $\mathrm{C} / \mathrm{G}$ genotype carriers had 72,5 and $27,5 \%$, respectively; G/G genotype carriers had 30,8 and $69,2 \%$, respectively. It was found out in the patients with $B A$ that $G / G$ homozygotes have higher ratio of fat centralization, than the major allele homozygotes or heterozygotes. The analysis of genotypes distribution depending on the ratio of fat centralization in patients with asthma showed a statistically significant difference $\left(Z^{2}=25,5 ; \quad\right.$ $=$ 0,001).

Therefore, the obtained data concerning the association of $\mathrm{G} / \mathrm{G}$ genotype for Bcll $\mathrm{GR}$ gene polymorphism with the occurrence of BA, obesity (particularly, visceral type) verify possible common genetic origin of these two diseases and pleiotropic features of Bcll polymorphism.

Molecular mechanisms of how Bcll polymorphism influences the occurrence of obesity are not clearly determined yet; they can be related to the direct influence of the Bcl1 polymorphism on GR gene expression, as well as to its possible influence on the transcriptional activity of target genes, involved in glucose and insulin homeostasis [10]. This polymorphism is probably connected with other polymorphisms in the promoter region of GR gene, as well as with other polymorphisms in other genes.

The mechanisms due to which the Bcll polymorphism can influence BA occurrence remain unclear. This influence can be possibly explained by the results of the studies demonstrating the effect of this polymorphism on sensitivity to glucocorticosteroids and obesity occurrence, which can induce BA and complicate BA course [10, 12].

The obtained results as for the association between Bcll GR gene polymorphism and occurrence of $\mathrm{BA}$ and obesity require further research on the complicated molecular mechanisms - this will enable better understanding of occurrence principles of obesity-associated BA, and will help to develop new individual therapy approaches, respectively.

Conclusions. It was found out that the patients with $\mathrm{BA}$ demonstrated higher $\mathrm{BMI}$ and ratio of fat centralization much more often, than the control group ( $ð=0,0001)$. Genotypes distribution for Bcll polymorphism in patients with BA showed a statistically significant difference between pa-tients with different BMI unlike the control group. G homozygotes had higher BMI, than those in the control group or with other genotypes. BMI didn't much differ between $\mathrm{C} / \mathrm{C}$ and $\mathrm{C} / \mathrm{G}$ geno-types carriers. Comparison of genotype frequency for Bcll GR gene polymorphism in individuals with different ratio of fat centralization in the control group and in the patients with BA sepa-rately showed statistically significant differences in the distribution of gene allelic variations among the patients with BA only. Among BA patients with $\mathrm{G} / \mathrm{G}$ genotype - $69.2 \%$ had visceral obe-sity. In case of normal ratio of fat centralization, there were no statistically significant differences in the distribution of allelic variations between the control group and in the patients with BA. It was found out that G/Ghomozygotes have a fivefold higher risk of BA, than those homozygous for $\mathrm{C} / \mathrm{C}$. We demonstrated that risk of visceral obesity in BA patients, homozygous for the minor allele, is 3.13 times higher, as compared with $\tilde{N} / \tilde{N}$-homozygotes (ð<0.001). 


\section{REFERENCES}

1. Shore, S.A., Obesity, airway hyperresponsiveness, and inflammation, J. Appl. Physiol., 2010, vol. 108, no. 3, pp. 735-743.

2. Baruwa, P., and Sarmah, K.R., Obesity and asthma, Lung India, 2013, vol. 30, no. 1, pp. 38-46.

3. Saint-Pierre, P., Bourdin, A., Chanez, P., Daures, J.P., and Godard, P., Are overweight asthmatics more dif-ficult to control?, Allergy, 2006, vol. 61, no. 1, pp. $79-84$

4. Hallstrand, T.S., Fischer, M.E., Wurfel, M.M., Afa-ri, N., Buchwald, D., and Goldberg, J., Genetic pleiotropy between asthma and obesity in a community-based sample of twins, J. Allergy Clin. Immunol., 2005, vol. 116, no. 6, pp. 1235-1241.

5. Dorevitch, S., Conroy, L., Karadkhele, A., Rosul, L., Stacewicz-Sapuntzakis, M., and Fantuzzi, G., Associations between obesity and asthma in a low-income, urban, minority population, Ann. Allergy Asthma Immunol., 2013, vol. 110, no. 5, pp. 340-346.

6. Nicolacakis, K., Skowronski, M.E., Coreno, A.J., West, E., Nader, N.Z., Smith, R.L., and McFadden, E.R.Jr., Observations on the physiological interactions between obesity and asthma, J. Apl. Physiol., 2008, vol. 105, no. 5, pp. 1533-1541.
7. Rosmond, R., The glucocorticoid receptor gene and its association to metabolic syndrome, Obes. Res., 2002, vol. 10, no. 10, pp. 1078-1086.

8. Buemann, B., Vohl, M.C., Chagnon, M., Chagn-on, Y.C., Gagnon, J., Perusse, L., Dionne, F., Desp-res, J.-P., Tremblay, A., Nadeau, A., and Bouchard, C., Abdominal visceral fat is associated with a Bcll restriction fragment length polymorphism at the glucocorticoid receptor gene locus, Obes. Res., 1997, vol. 5, no. 3, pp. 186-192.

9. Tesse, R., Schieck, M., and Kabesch, M., Asthma and endocrine disorders: shared mechanisms and genetic pleiotropy, Mol. Cell Endocrinol., 2011, vol. 333, no. 2, pp. 103-111.

10. Van Rossum, E.F., and Lamberts, S.W., Polymorphisms in the glucocorticoid receptor gene and their associations with metabolic parameters and body composition, Recent Prog. Horm. Res., 2004, vol. 59, pp. 333-357.

11. Ukkola, O., Perusse, L., Chagnon, Y.C., Despres. J.P., and Bouchard, C., Interactions among the glucocor-ticoid receptor, lipoprotein lipase and adrenergic receptor genes and abdominal fat in the Quebec Fa-mily Study, Int. J. Obes. Relat. Metab. Disord., 2001, vol. 25, no. 9, pp. 1332-1339.

12. Pietras, T., Panek, M., Tworek, D., Oszajca, K., Wujcik, R., Gorski, P. Kuna, P., and Szemraj, J., The Bcll single nucleotide polymorphism of the human glucocorticoid receptor gene h-GR/NR3C1 pro-moter in patients with bronchial asthma: pilot study, Mol. Biol. Rep., 2011, vol. 38, no. 6, pp. 3953-3958.

13. Weaver, J.U., Hitman, G.A., and Kopelman, P.G., An association between a Bc1l restriction fragment length polymorphism of the glucocorticoid recep-tor locus and hyperinsulinaemia in obese women, $J$. Mol. Endocrinol., 1992, vol. 9, no. 3, pp. 295-300.

14. Srivastava, N., Prakash, J., Lakhan, R., Agarwal, C.G., Pant, D.C., and Mittal, B., Influence of Bcl-1 gene polymorphism of glucocorticoid receptor gene (NR3C1, rs41423247) on blood pressure, glucose in Northern Indians, Indian J. Clin. Biochem., 2011, vol. 26, no. 2, pp. 125-130.

15. Fleury, I., Beaulieu, P., Primeau, M., Labuda, D., Sinnett, D., and Krajinovic, M. Characterization of the Bcll polymorphism in the glucocorticoid receptor gene, Clin. Chem., 2003, vol. 49, no. 9, pp. 1528-1531. 